\title{
Children's playground accessibility in the North of Portugal
}

\author{
Beatriz Pereira \\ University of Minho
}

\begin{abstract}
With the growing significance of sedentary activities, such as television-watching, playgrounds remain important leisure facilities for children, since physical play activities have an important role in supporting children's motor, social and emotional development. When children have the opportunity to play in a playground they are promoting healthy lifestyles. In Portugal children are required to attend school until the age of 16 years and are provided with education, which is regulated by national government standards, but in regard to leisure opportunities, there is considerable inequality of provision from locality to locality.

Seeking to promote the principles of play and health in the open air, a project was developed to discover the pattern of provision of children's playgrounds in different regions of the North of Portugal and to examine their physical characteristics. A questionnaire was developed and sent to Town Halls, seeking information on playground provision in each district and on the characteristics of the equipment provided in the playgrounds. This study includes four sub-regions - Ave, Cávado, Minho-Lima, Alto Trás-os-Montes - that include 38 districts. The north region of Portugal covers $21.194 \mathrm{~km}^{2}$ and is occupied by more than 3.600 .000 inhabitants. The region has one of European youngest populations.

It was found that almost half of the districts surveyed provided less than 5 playgrounds in their area. Children in general therefore have few opportunities to play in playgrounds because of lack of provision and have very few opportunities to choose the activities they like to engage in because of the lack of attractive equipment. Playgrounds are located mostly in areas without heavy traffic and the majority of playgrounds have minimal equipment - typically four or less items. The paper discusses the implications of these findings for policy-makers in the region.
\end{abstract}

Keywords: Children; playgrounds; play; equipment

\section{Introduction'}

The concept of leisure, is an ample and open concept, encompassing multiple activities and to the different levels of experience. When we think about leisure we think about practices like games, sports, cultural practices and contact with nature (Pereira et al., 2000). Leisure includes sports, watching television,

1 This study is part of a wider project called "Leisure spaces for children", which received financial support from the Commission for the Coordination of the North Region of Portugal.

\section{* * *}

travelling, reading, going to the theatre or doing voluntary work in structured or informal organizations. Leisure may imply individual or collective effort, but it also includes doing nothing.

The first step of this project was to develop a taxonomy that would include many different spaces where leisure takes place. This task was very important, because leisure is a wide subject and we wanted to get information about different spaces on the same topics. We developed this taxonomy in four categories of 
spaces: play spaces, spaces for sports, cultural spaces and green areas.

In this article, we will only approach play spaces, and more specifically playgrounds.

The main goal of this study was to identify, describe and compare the playgrounds of four regions in the North of Portugal (Ave, Cávado, Alto Trás-os-Montes and Minho-Lima). The north region of Portugal has $21.194 \mathrm{~km}^{2}$ and over 3.600.000 inhabitants and is one of the regions in Europe with youngest population.

We will try to find out if the number of playground by region is sufficient and if playground resources are equitably distributed. We want to know about the accessibility of play areas for children and the opportunities they have to play in qualified and safe playgrounds. The concept of equitable may have several meanings, which we will try to clarify. We understand that playgrounds should be well distributed to provide approximately equal access to all children (more playgrounds where there are more children). In urban areas there are more children and they are relatively more deprived of access to safe play. In urban areas there are parents with better social economics background but also very poor children for whom the playground can be the unique opportunity to play. We understand that urban areas have more children consequently they should have more playgrounds than in rural areas. We are talking about median towns with services and commercial areas but also where people live.

It is important to define the concepts used in this study. Playgrounds are recreational places made for children's leisure and not considered as places for sports. The DecreeLaw n. $379 / 97$, December $27^{\text {th }}$, defines playground as "an area destined to children's leisure, with spatial and functional limits, where physical activity plays an important role". The concept of a playground is changing as result of a new regard to children play and what are their needs and what they like to play.

The differences between regions can be explained according to economic and demographic standards. We can divide the four regions in two: one with more dynamic economic and demographic conditions (Ave and Cávado - $\mathrm{AC}$ ), and the other poorer and with older population (Minho-Lima and Alto Trásos-Montes - MA).

The resident population has grown very much from 1991 to 1998 in AC, more than the national average, and practically hasn't grown in Minho-Lima. AC have much younger population and a high birth rate, higher than national average, while Minho-Lima has a lower birth rate than national average. The density of the population in 1998 was medium in $\mathrm{AC}$, higher than national average, and low in Minho-Lima, but still higher than national average. The weight of the intracommunitary commerce is very high in $\mathrm{AC}$, higher than national average, while in Minho-Lima it is lower than national average (Ribeiro; Cabral and Sousa, 2000).

Concerning the employment, in $A C$ it is more connected to the transformation industries, textiles, clothes and leather, with higher values than national average, and in MinhoLima it is more connected to commerce and transportation. Many enterprises have been created in $\mathrm{AC}$, more than the national average, and less than the national average in MinhoLima (Ribeiro; Cabral and Sousa, 2000).

Concerning the region of Alto Trás-osMontes, it is located in the interior of the country and has the same characteristics as MinhoLima, only more accentuated.

We concentrated our work on public playgrounds in the regions we referred. We have included in our database playgrounds in schools and kindergarten, whenever accessible to children when they are not in classes. Playgrounds in malls, restaurants and other private institutions were not taken into account in this study.

With the growing significance of sedentary activities, such as television-watching, playgrounds remain important leisure facilities for children, since physical play activities have an important role in supporting children's motor, social and emotional development. In Portugal children are required to attend school until the age of 16 years and are provided with education, which is regulated by national government standards, but in regard to leisure opportunities, there is considerable inequality of provision from locality to locality. 
Playgrounds are recreational areas for children where they can go in their free time, meet play colleagues, which is an important support for socialization, and develop motor skills. Playgrounds can also contribute to healthy and active life routines.

Playgrounds play an important role in children's development and they are very complex, justifying profound studies, assuring children's right to play safely, according to the International Convention of Children's Rights.

As result of the literature review about playground, we did not get information about a standard for levels of playgrounds provision in Portugal or even in others countries. We got this standard for the provision of sports equipments.

Playground's safety is an important matter. Children's motor skills and safety conditions of playgrounds should be studied, concerning the location, conception, construction and organization of playgrounds.

One factor that leads to accidents in playgrounds is children's motor illiteracy, mostly due to life conditions in society in general and concerning families in particular (Neto, 1997). According to this author, today's society is more urban and families, though they have more free time, have lower quality of life, which reflects in children's daily routine. Changes are occurring in streets, in physical activity, in the autonomy and in recreational spaces.

However, to understand accidents in playgrounds, researchers mainly study the equipment and impact surfaces. In the "National Survey of Community Playground" (Hudson, 1989 ) researchers stated that in $75 \%$ of the community playgrounds, the distance between equipment was approximately 3 meters. This distance is a safety measure that should be taken as reference in the construction of playgrounds (Hudson, 1989: 30). Tinsworth (1996: 46) concluded that climbing equipment was responsible for most of the accidents.

It is necessary to improve the safety of the equipment to reduce accidents. It should be a permanent concern of the local governments to assure the preservation of playgrounds. Then it is necessary to periodically verify the conditions of the equipment. Detailed infor- mation about playgrounds helps to know the design they should have.

Spaces for children to play close to theirs homes are necessary to promote motor development and children's autonomy. This fact is gaining more impact in the last decades because children live in flats, with small rooms and without place to play. Children play in a building area (recreational play, playgrounds) but also in informal areas (streets and parks) where they can make friends, learn to be autonomous and play.

Streets are ample spaces, excellent for children's motor development and autonomy, but nowadays they are no longer safe, due to the traffic (Neto, 1997: 15), to the increasing criminality (Cabaćo, 1991: 213) and to the decrease of free spaces owing to building priorities; in suburban areas, lack of quality public spaces is due to the construction of massive and inhuman buildings. Generally the urbanistic architecture does not account for the leisure and motor needs of children (Mota \& Rodrigues, 1999).

Concerning physical activity, we state that the decrease of play opportunities (spaces and friends) leads to the substitution of active games by electronic games and to a growing sedentary culture (Serrano \& Neto, 1997: 209).

Autonomy is associated with motor development. The conquest of the space surrounding the residence is compromised. That space is essential for the development of child's autonomy (Pfister, 1991). In rural places, autonomy progressively increases, while in urban places it is limited to the residential area. On this matter, Neto (1997: 15) says "the level of autonomy in the course house/school, decreases considerably when we approach urban centres". Children have problems accessing green areas and making friends.

The "United States Consumer Product Safety Commission" (USCPSC, 1980) published rules for playgrounds and their equipment. Concerning accessibility and location of the equipment, they recommended there should be visibility between spaces to avoid kidnapping and enable better supervision. There should be barriers surrounding the playground to avoid accidents when children run 
out of the playground. Accessibility should also be permitted to children in wheel chairs (Hudson, 1989: 28-29).

According to these explainations, some playgrounds are not safe for children, but there are other serious problems less visible like bullying and violence against children that can transform some playgrounds, even when they are very interesting, into deserted playgrounds, without children.

Playgrounds in schools are deserted areas where children have few opportunities to play. This poor environment is associated with bullying, which negatively affects children (Pereira, 2002). Bullying consists of the victimization of a student repeatedly exposed to negative actions by one or more of his colleagues (Olweus, 1991). Smith and Sharp (1994: 2) describe bullying as the systematic abuse of power. Marques, Neto and Pereira (2001), in a study about school playgrounds (empty, with equipment and with supervision), concluded that in playgrounds with equipment there was less bullying.

In a research that linked rough-and-tumble play with social competence, social leadership and dominance behaviour, Pellegrini and Smith (1998) concluded that children choose soft soils such as grass or sand because they attenuate the impact of the fall. In fact, children want to play and not to cause injuries to their peers.

Child and youngsters enjoy putting themselves at risk, and this is necessary for their development. Consequently, more game opportunities must be created to increase children's physical development enabling them to measure risk. The existence of recreational spaces favours children's practices (Pereira, Neto, Smith \& Angulo, 2002).

\section{Methods}

We've send by post questionnaires to all Town Halls (38) of these four regions. We got answers for 37 , one did not answer. In all cases we also contact them more than once to clarify any doubts. We have a phone and e-mail address that was used by the technicians of the different districts to clarify some questions. In the cases requested by the Town Halls, one member of this project trained to do interview, will do it to collect the information, in an appointment for this purpose. In fact we have a questionnaire as support but this was administrated as an interview. This can explain why in only one case we did not got the information. We got the data step by step; we only worked in one region each time. Only when we have finished one region we began another.

We collected the data in 1999, 2000 and 2001 with a questionnaire that was answered by technical staff of Town Halls in the four regions included in this study. We complemented this information with other sources, such as documents of the local government and direct observation of the spaces. Below, we are going to describe the interview we did.

Interviews

The interviews focused on the following topics:

a) General description: global location (urban/rural area); year of construction; size.

b) Characteristics of the surface, fence, material of the equipment and support equipment - regarding the surface of the playground, we asked about the materials used in the main surface and impact surface (dirt, sand, wood, concrete or a synthetic material), whether there was a fence, and what it was made of (bushes, concrete, wire fence, wood).

We also asked what kind of equipment was available, and whether it was mainly made out of metal, wood or a synthetic material.

c) Types of playgrounds and equipment: playgrounds (single or recreation facilities); traditional or new design (repetitive or multiple tasks); equipment (simple or multipurpose); pieces of equipment.

d) Management - we asked who were the owners and the managers in charge of the maintenance.

e) Safety and maintenance - we inquired about the conditions of use and safety.

f) Accessibility and playgrounds' usage we asked who the most common users were. Were they common people, associations, clubs or schools? Were the playgrounds used year round or seasonally, and did children go there everyday or only on weekends? How did children get to the playground? By foot, taken by their parents by car or by bus? What was 


\section{Beatriz Pereiro}

Figure 1 - Number of playgrounds per region

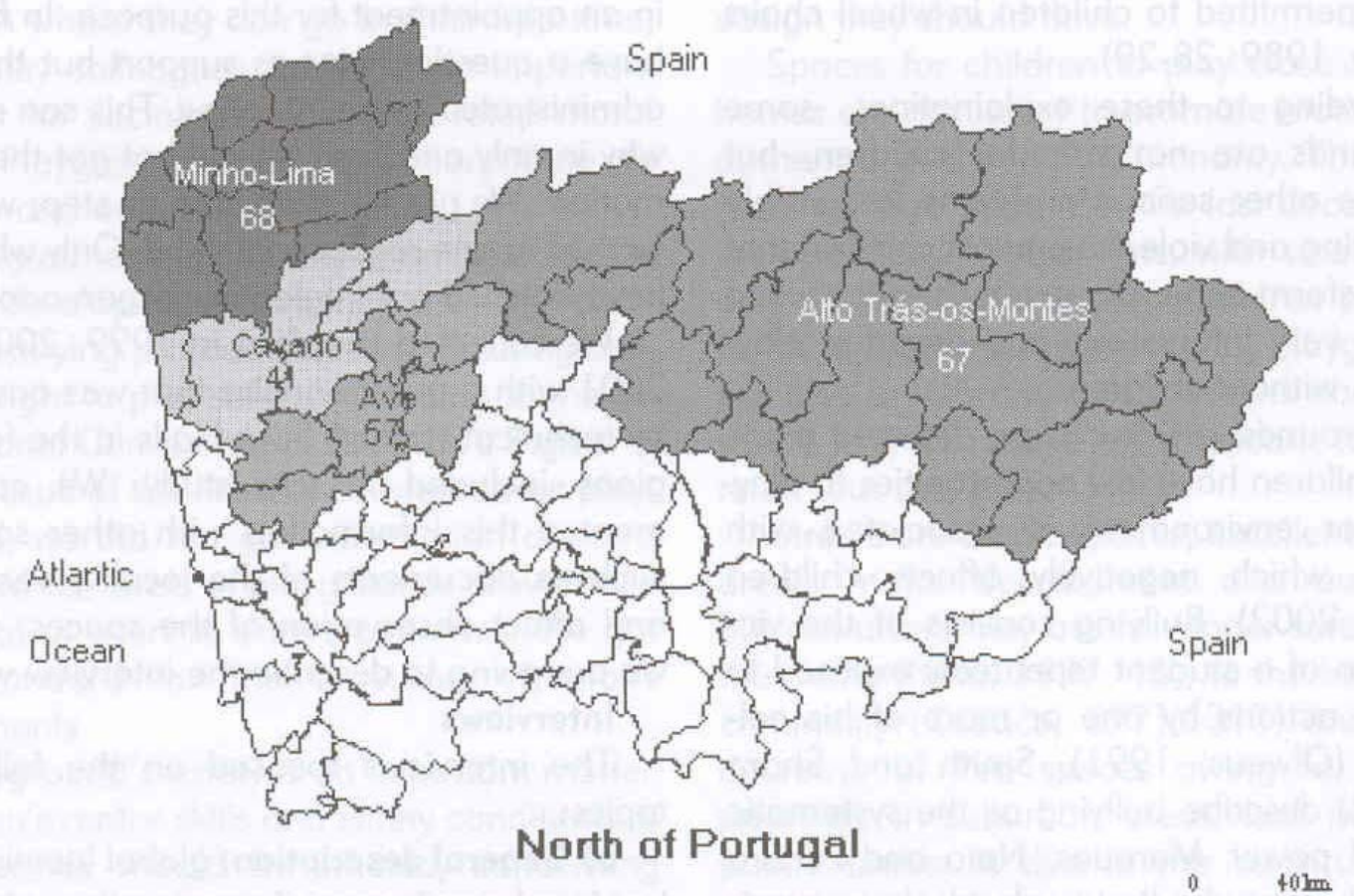

the playground's specific location (residential area, green space, area for sports, commercial area, etc.)?

A database was created and treated with the software Statistical Package for the Social Sciences (SPSS).

\section{Results}

3.1. Geographic distribution of playgrounds Among the 233 playgrounds we counted in the 38 districts of the four regions in the North of Portugal, there are 98 playgrounds in Ave and Cávado (more urban regions with high economic and demographic standards) and
135 in Alto Trás-os-Montes and Minho-Lima (more rural regions with low economic and demographic standards). There is considerable inequality in provision of playgrounds when we compare the two regions.

Minho/Lima and Alto Trás-os-Montes have more playgrounds, 68 and 67, while Ave has 57 and Cávado 41 playgrounds (Figure 1). We didn't get information concerning the number of playgrounds in one district.

The regions with fewer playgrounds (Ave and Cávado) have more population than the other two regions and have more children (0-14 years old) (Table I).

Table I. Playgrounds, resident population and children per region

\begin{tabular}{lcccc}
\hline Regions & $\begin{array}{c}\text { Resident } \\
\text { population* }\end{array}$ & $\begin{array}{c}\text { Children 0-14 } \\
\text { years old** }\end{array}$ & $\begin{array}{c}\text { Number of } \\
\text { playgrounds }\end{array}$ & $\begin{array}{c}\text { Index playgrounds/ } \\
1000 \text { children }\end{array}$ \\
\hline Ave & 508674 & 96480 & 57 & 0,59 \\
\hline Cávado & 392672 & 77370 & 41 & 0,53 \\
\hline Alto Trás-os-Montes & 223037 & 32580 & 67 & 2,06 \\
\hline Minho/Lima & 249848 & 39800 & 68 & 1,71 \\
\hline Ave + Cávado & 901346 & 173850 & 98 & 0,56 \\
\hline Alto Trás-os-Montes + Minho-Lima & 472885 & 72380 & 135 & 1,86 \\
\hline Total & 1374231 & 246230 & 233 & \\
\hline Global index & & & & 0,95 \\
\hline
\end{tabular}

* Resident population: Censos 2001 - provisional data. Instituto Nacional de Estatística/Direcção Geral de Ordenamento do Território e Desenvolvimento Urbano.

** Children 0-14 years old: I.N.E, estimations for 1998 
Regions with less and older populations have higher playground provision, although there are few children. The average of the four regions is less than one playground per 1000 children. According to these results, the access to the playground seems difficult in children's daily routine. Maybe if children were questioned how many times they had been to a playground, there would be many who would say never. For more rural regions they have around one playground for 500 children. However for more urban regions they have one playground for approximately 2000 children. Towns are growing up quickly in opposition to non-urban areas which are decreasing their population.

When we analyse the number of playgrounds by district, we state that there are big differences between them: we have from 0 to 22 playgrounds, depending on the district. There are many districts with few children that have many playgrounds. In the region of Minho-Lima, there is a district with one playground for 72 children and another with one playground for 60 children.

The number of playgrounds per 1000 children for each district goes from the minimum of zero to the maximum of 16,8. Among the 38 districts studied, 10 have one or more playgrounds for 500 children, 11 have more than one but less than two playgrounds for 1000 children and 15 have less than one playground for 1000 children.

There are three aspects to retain: playgrounds are scarce, accounting for the number of children ( $0-14$ years old) in each district; there are differences between and inside the various regions; districts with more children ( $>10000$ children) and more resident
Figure 2 - Location of the playgrounds

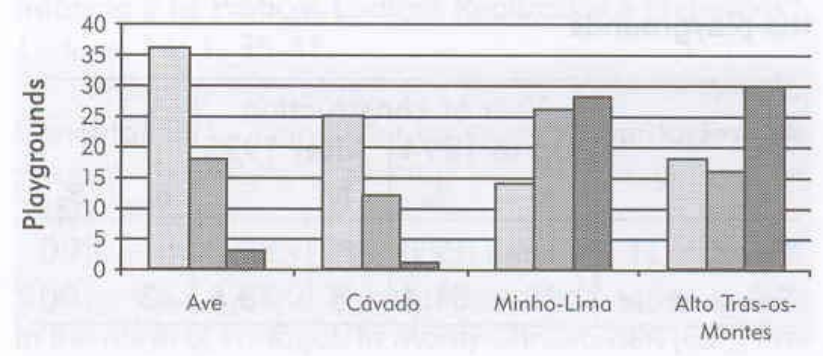

$\square$ Predominantly urban areas $\square$ Medium urban areos $\square$ Predominantly rural areos

population ( $>50000$ inhabitants) have less than one playground for 1000 children.

\subsection{Location of the playgrounds in urban or rural areas}

According to figure 2, the regions of Ave and Cávado have more playgrounds in urban areas, while Minho/Lima and Alto Trás-osMontes have more playgrounds in rural areas than in urban areas.

\subsection{Year of construction and preservation}

Most of the playgrounds were built in the 1990 s and $32 \%$ of them were built between 1995 and 1999 (Table II). This information on the year of construction is missing in more than $60 \%$ of the cases in $A C$ and in less than $50 \%$ in MA.

The preservation of the playgrounds was considered good in $54,9 \%$ of the cases that answered to this question, reasonable in 37\% and bad in $8,5 \%$ of the cases, according to the opinion of the people interviewed in Town Halls.

The districts in the region of Alto Trás-osMontes have most of the playgrounds in good conditions (they also have the most recently built playgrounds). $80 \%$ of the playgrounds in good conditions were built after $1995.78 \%$ of

Table II. Year of construction of the playgrounds by region

\begin{tabular}{|c|c|c|c|c|c|c|c|c|c|c|c|c|c|}
\hline \multirow[t]{2}{*}{ Region } & \multicolumn{2}{|c|}{ Up to 1969} & \multicolumn{2}{|c|}{$1970-1979$} & \multicolumn{2}{|c|}{$1980-1989$} & \multicolumn{2}{|c|}{ 1990-1994 } & \multicolumn{2}{|c|}{ 1995-1999 } & \multicolumn{2}{|c|}{ Missing cases } & \multirow{2}{*}{$\begin{array}{c}\text { Total } \\
\mathrm{N}\end{array}$} \\
\hline & $\mathrm{N}$ & $\%$ & $\mathrm{~N}$ & $\%$ & $\mathrm{~N}$ & $\%$ & $\mathrm{~N}$ & $\%$ & $\mathrm{~N}$ & $\%$ & $\mathrm{~N}$ & $\%$ & \\
\hline Ave & 1 & 1,8 & 1 & 1,8 & 1 & 1,8 & 15 & 26,3 & 4 & 7 & 35 & 61,4 & 57 \\
\hline Cávado & - & - & - & - & - & - & 1 & 2,4 & 12 & 29,3 & 28 & 68,3 & 41 \\
\hline Minho-Lima & 1 & 1,5 & 2 & 2,9 & 4 & 5,9 & 4 & 5,9 & 25 & 36,8 & 32 & 47,1 & 68 \\
\hline Alto Trás-os-Montes & - & - & 5 & 7,5 & & 16,4 & 6 & 9 & 34 & 50,7 & 11 & 16,4 & 67 \\
\hline Total (N) & \multicolumn{2}{|c|}{2} & \multicolumn{2}{|c|}{8} & \multicolumn{2}{|c|}{16} & \multicolumn{2}{|c|}{26} & \multicolumn{2}{|c|}{75} & \multicolumn{2}{|c|}{106} & 233 \\
\hline
\end{tabular}


Table III. Year of construction and appreciation of the playgrounds

\begin{tabular}{l|cc|cc|ccc}
\hline \multirow{2}{*}{ Appreciation } & \multicolumn{3}{|c|}{ Year of construction } & \multicolumn{2}{c}{ Total } \\
& Up to 1994 & \multicolumn{2}{|c|}{ Ufter } & 1995 & \multicolumn{2}{c}{ No } \\
& N & $\%$ & N & $\%$ & N & $\%$ \\
\hline Good & 16 & 19,8 & 65 & 80,2 & 81 & 100 \\
Reasonable & 35 & 81,4 & 8 & 18,6 & 43 & 100 \\
\hline
\end{tabular}

the playgrounds reasonably preserved were built until 1994, just as all the playgrounds in bad conditions. The more recent the playgrounds, the better preserved it is, as expected. However, there are other factors related to the preservation of playgrounds: their maintenance, location in non-degraded areas and vandalism, that can destroy in a few hours something that took much time to build.

\subsection{Traffic}

Concerning traffic around playgrounds, $64,5 \%$ of the valid cases indicate they are in areas of little traffic, like residential areas or squares. $18 \%$ of the playgrounds are located in areas of high traffic and $18 \%$ in pedestrian areas (Figure 3 ).

Figure 3 - Traffic around playgrounds

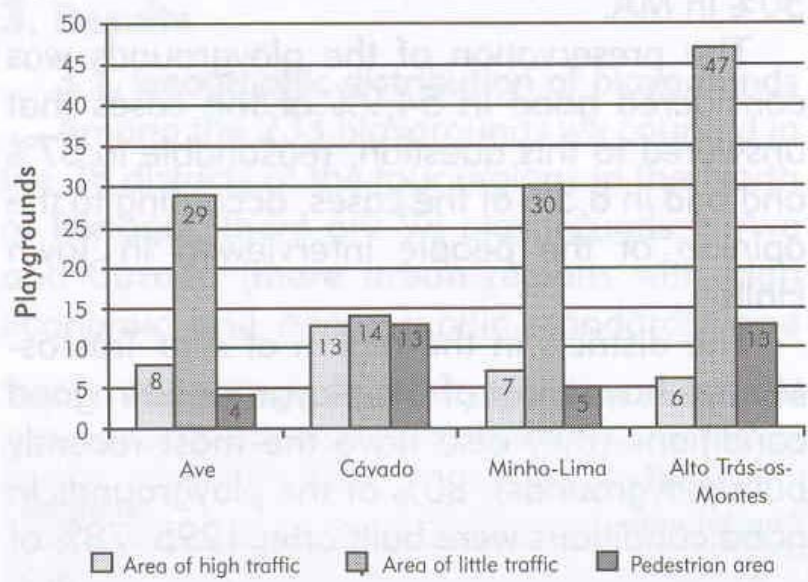

Alto Trás-os-Montes is the region with more playgrounds in areas of little traffic.

When playgrounds are located in areas of much traffic, it is necessary to implement technical solutions to assure children's safety.

\section{Conclusions and recommendations}

The most important aspects of this paper refers to the lack of playgrounds and their unequal distribution intra and interregionally.
The lack of playgrounds is more evident in densely populated areas, where the ratio number of playgrounds/number of children is lower, which shows some lack of attention from the local governments to the provision of spaces and equipment for children. We concluded that there is considerable inequality of provision from locality to locality, which is an important factor to determine low accessibility to playgrounds.

We can see there are more playgrounds in areas of intense traffic in more urbanized districts, as expected. Playgrounds in areas of much traffic should integrate technical solutions, which are consecrated in the law, to reduce the risk of accident, which is inherent to play.

The provision of playgrounds seems to be more related to economic standards, more centred in urban areas in districts with more economic power and more centred in rural areas in poorer regions, even if the concentration of the population is the same.

As a recommendation, we would suggest bigger concern with leisure policies for children by local governments, accounting for the low ratio of playgrounds/children in the districts with more resident children.

The planning of a playground should be based on the possible demand by children who live in the district or parish. New urbanizations should have play spaces for children, predicting the normal population growth, usually higher in poor social backgrounds.

Although it was difficult to know the year of construction of many playgrounds, due to the lack of an inventory, the construction of playgrounds was intensified in the 1990s, particularly in the last five years of the decade, which shows a growing concern with leisure policies for children by local governments.

According to the opinion of the people we interviewed in Town Halls, the preservation of the playgrounds is predominantly considered to be good. Playgrounds built after 1995 are, in majority, well-preserved, contrary to what happens to playgrounds built until 1994.

Regular maintenance, followed by repair or remodelling of older playgrounds, are crucial to a good preservation. Vandalism, which aims the destruction of the spaces, is more 
frequent in the months following the construction of the playgrounds, if no measures are taken. The progressive degradation of the equipment is much slower.

In conclusion, we recommend higher provision of playgrounds services in all regions. We give some reference in the index of children by playground by region and for all regions. The standard for levels of playground provision should include as an important factor the number of children. However there is more than one variable that should be studied and included to take decision about provision of playgrounds: number of children by region, number of parish by region, area of each one and number of children per parish. From this macro study it is necessary to come to a local and micro study.

\section{REFERENCES}

Cabaćo, J. (1991). "Os espaćos desportivos de lazer e recreaćāo e a prevenção da delinquência". In Câmara Municipal de Oeiras (Ed.), Congresso europeu desporto para todos. Os espaćos e os equipamentos desportivos. Oeiras, Câmara Municipal de Oeiras, pp. $213-221$.

Hudson, S. (1989). "Location, accessibility and equipment on park playgrounds". In Donna Thompson and Louis Bowers, Where our children play. Community park playground equipment. Reston, American Alliance for Health, Physical Education, Recreation and Dance.

Instituto Nacional de Estatística/Direcção Geral de Ordenamento do Território e Desenvolvimento Urbano (1999). Indicadores Urbanos do Continente. Lisboa. INE.

Marques, A. R.; Neto, C. \& Pereira, B. O. (2001). "Changes in school playground to reduce aggressive behaviour". In Martinez, M. (Ed.). Prevention and control of aggression and the impact on its victims. New York, Kluwer Academic/Plenum Publishers, 137-145.

Mota, J. \& Rodrigues, S. (1999). Jogo e espaços lúdicos infantis. Oeiras. Câmara Municipal de Oeiras.

Neto, C. (1997). Tempo e espaço de jogo para a criança. In Neto, C. Jogo e desenvolvimento da criança. Lisboa, Edições Faculdade de Motricidade Humana, Universidade Técnica de Lisboa.

Olweus, D. (1991). "Bully/victim problems among schoolchildren: Basic facts and effects of a school based intervention program". In D. Pepler \& K. Rubin (eds). The Development and Treatment of Childhood Aggression. Hillsdale, N. J.: Erlbaum.

Pereira, B. (2002). Para uma escola sem violência: estudo e prevenção das práticas agressivas entre crianças. Lisboa, Fundação Calouste Gulbenkian/ Fundação para a Ciência e a Tecnologia.
Pereira, B. O. \& Neto, C. (1994). "O Tempo Livre na Infância e as Práticas Lúdicas Realizadas e Preferidas". Ludens, 14, 1, 35-41.

Pereira, B. O.; Neto, C.; Smith, Peter \& Angulo, Carlos (2002). "Reinventar los espacios de recreo para prevenir la violencia escolar". Cultura y Educación, 14(3), 297-311.

Pereira, M. B. O.; Malta, P.; Laranjeiro, H.; Sousa, T. B.; Coquet, E. (2000). Public playgrounds' safety: a study in the north of Portugal. In Monty Christiansen (ed.), Proceedings: Playground Safety 1999 - An International Conference, Pennsylvania, Penn State University Park.

Pfister, G. (1991). "Integraçāo no ambiente, experiências motoras e actividades desportivas de raparigas e mulheres". In Câmara Municipal de Oeiras (Ed.), Congresso Europeu Desporto para todos. Os espaços e os equipamentos desportivos. Oeiras, Câmara Municipal de Oeiras, pp. $129-140$.

Ribeiro, J. C., Cabral, D. and Sousa, R. (2000), Indicadores de desempenho económico - NUT do Vale do Cávado: análise comparativa com as principais NUT III do Continente, o Continente e a Galiza, Braga, Escola de Economia e Gestăo, Universidade do Minho. Exemplar policopiado.

Serrano, J. \& Neto, C. (1997). "As rotinas de vida diária das crianćas com idades compreendidas entre os 7 e os 10 anos nos meios rural e urbano". in Jogo e desenvolvimento da crianća, Lisboa, Edições FMH, UTL.

Smith, P. K. \& Sharp, S. (1994). "The problem of school bullying". In Smith, P. K. \& Sharp, S. School Bullying. Insights and perspectives. London, Routledge.

Tinsworth, D. (1996). "Public playground equipment - related injuries and deaths". in Christiansen, $M$. e Vogelsong H. (eds.), Play it safe. An anthology of playground safety. Virginia, National Recreation and Park Association.

United States Consumer Product Safety Commission (1980). Handbook for Public Playground Safety, Washington D. C.

\section{Legislation}

Decree-Law n. 379/97, December $27^{\text {th }}-$ Safety conditions for recreational spaces.

$$
\text { * * * }
$$

BEATRIZ PEREIRA, Associate Professor University of Minho, Institute of Child Studies, Portugal

Author's contact:

Beatriz Pereira (PhD), University of Minho Institute of Child Studies

Av. Central, $n^{\circ} 100,4710-229$ Braga, Portugal

Telefone: (directo) +351 253601205 (geral) +351 253601200

E-mail: beatriz@iec.uminho.pt Fax: +351 253616684

This study was supported by the Commission for the Coordination of the North Region of Portugal 